\title{
Validity and reliability of the Inflammatory Bowel Disease Fatigue Scale in Mexican patients
}

\author{
Norma N. Parra-Holguín, ${ }^{1}$ Ana Fresán-Orellana² and Jesús K. Yamamoto-Furusho ${ }^{1 *}$ \\ 'Inflammatory Bowel Disease Clinic, Instituto Nacional de Ciencias Médicas y Nutrición Salvador Zubirán; '2Laboratory of Clinical Epidemiology, \\ Sub-directorate of Clinical Research, Instituto Nacional de Psiquiatría Ramón de la Fuente Muñiz. Mexico City, Mexico
}

\begin{abstract}
Introduction: Fatigue is an extra-intestinal manifestation of inflammatory bowel disease (IBD). Objective: To determine the construct validity, discriminant validity and reliability of an instrument for evaluating the Fatigue Scale for IBD in Mexican patients. Methods: Two hundred patients with an IBD confirmed diagnosis were included. Current demographic and clinical characteristics of the condition were evaluated. Each patient answered the IBD Fatigue Scale (IBD-F) and the Pittsburgh Sleep Quality Index (PSQI), which was used to determine IBD-F discriminant validity. A factor analysis of each IBD-F section was performed, independent sample Student's t-tests were used to contrast the PSQI, and reliability was evaluated using Cronbach's alpha. Results: The items in both IBD-F sections showed high factor loadings, which explained 68.3 and $38.4 \%$ of variance, respectively. Cronbach's alpha was $>0.80$ in both, which discriminated patients with greater sleep disturbances. Conclusions: IBD-F is a valid and reliable scale for Mexican patients with IBD. Fatigue objective evaluation will allow timely interventions in order to reduce its impact on patients with IBD.
\end{abstract}

KEY WORDS: Fatigue. Validity. Reliability. Inflammatory bowel disease. Mexico.

\section{Validez y confiabilidad de la Escala de Fatiga para la Enfermedad Intestinal Inflamatoria en pacientes mexicanos}

\section{Resumen}

Introducción: La fatiga es una manifestación extraintestinal de la enfermedad inflamatoria intestinal (EII). Objetivo: Obtener la validez de constructo, la validez discriminante y la confiabilidad de un instrumento para evaluar una escala de fatiga para Ell en pacientes mexicanos. Métodos: Se incluyeron 200 pacientes con diagnóstico confirmado de Ell. Se evaluaron las características demográficas y clínicas actuales del padecimiento. Cada paciente contestó la Escala de Fatiga para EII (IBD-F) y el Índice de Calidad de Sueño de Pittsburgh (PSQI), empleado para determinar la validez discriminante de la IBD-F. Se realizó un análisis factorial de cada sección de la IBD-F, se utilizó la t de Student de muestras independientes para el contraste del PSQI y la confiabilidad se evaluó mediante alfa de ZCronbach. Resultados: Los reactivos de ambas secciones de la IBD-F mostraron altas cargas factoriales, que explicaron 68.3 y $38.4 \%$ de la varianza, respectivamente. El alfa de Cronbach $f u e>0.80$ en ambas, las cuales discriminaron a los pacientes con mayores alteraciones en el sueño. Conclusiones: La IBD-F es una escala válida y confiable para pacientes mexicanos con Ell. La evaluación objetiva de la fatiga permitirá realizar intervenciones oportunas para disminuir el impacto de esta manifestación en el paciente con Ell.

PALABRAS CLAVE: Fatiga. Validez. Confiabilidad. Enfermedad inflamatoria intestinal. México.

Correspondence:

*Jesús K. Yamamoto-Furusho

E-mail: kazuofurusho@hotmail.com
Date of reception: 04-09-2020

Date of acceptance: 01-10-2020

DOI: 10.24875/GMM.M21000574
Gac Med Mex. 2021;157:350-355

Contents available at PubMed

www.gacetamedicademexico.com

0016-3813/@ 2021 Academia Nacional de Medicina de México, A.C.. Published by Permanyer. This is an open access article under the CC BY-NC-ND license (http://creativecommons.org/licenses/by-nc-nd/4.0/). 


\section{Introduction}

Inflammatory bowel disease (IBD) includes chronic idiopathic ulcerative colitis, Crohn's disease and indeterminate colitis, and is characterized for being autoimmune, chronic, with intestinal tract involvement. A commonly reported symptom during patient consultation is fatigue, which might occur due to the presence of inflammatory cytokines ${ }^{1}$. Fatigue is defined as a lack of energy or exhaustion not proportional to physical effort, with limitation of daily living activities, which is not relieved with rest ${ }^{2}$; or as a sense of continuing tiredness, with periods of sudden and overwhelming lack of energy, or feeling of exhaustion that is not completely relieved following rest or sleep ${ }^{3}$. Fatigue is one of the symptoms with the highest impact on quality of life ${ }^{4}$, which can affect social, labor and emotional areas, and daily activities of the patient with IBD. It can occur regardless of age, gender ${ }^{5}$ or IBD clinical activity ${ }^{6}$. Some studies have reported the presence of fatigue in up to $50 \%$ of patients with IBD, in $62 \%$ of those who suffer from Crohn's disease, and in $47 \%$ of those with chronic idiopathic ulcerative colitis in areas with a high incidence of $\mathrm{IBD}^{7,8}$. Data in Mexico ${ }^{9}$ report a frequency of mild-moderate fatigue symptoms in $55.5 \%$ and severe fatigue in $31.5 \%$ of patients. Despite being one of the most frequent symptoms in patients with IBD, it is common for evaluation not to be carried out in regular clinical practice and for the required interventions not to be provided.

Currently, there are various instruments that assess fatigue, among which the Fatigue Severity Scale ${ }^{10}$, validated for infectious and autoimmune diseases ${ }^{11,12}$ and the Functional Assessment Scale of Chronic IIIness Therapy-Fatigue (FACIT-F) ${ }^{13}$, which initially was approved for patients with cancer and other chronic terminal diseases, stand out. However, it has been suggested that these instruments are not entirely suitable to be used in all chronic diseases, since the causes that give rise to fatigue tend to be different for each disease and should be validated in the specific population they will be used in. ${ }^{14}$ It was until 2014 that the IBD Fatigue Scale (IBD-F) was developed in the United Kingdom ${ }^{15}$, which was successfully validated in its population. Since then, the IBD-F scale has been reproduced in other countries for its use and evaluation, with positive results.

So far, in Mexico there is no validation of the IBD-F instrument, which would allow having an objective scale to assess fatigue and, consequently, better multidisciplinary management in order to carry out timely interventions for improving quality of life in IBD, which is frequently decreased in comparison with that of healthy patients ${ }^{16}$. Thus, the purpose of this study was to obtain the IBD-F scale construct validity, discriminant validity and reliability in Mexican patients with IBD, by evaluating internal consistency.

\section{Methods}

Cross-sectional process study carried out at the Inflammatory Bowel Disease Clinic of Salvador Zubirán National Institute of Medical Sciences and Nutrition (INCMNSZ - Instituto Nacional de Ciencias Médicas y Nutrición Salvador Zubirán). The study was approved by the Ethics and Research Committee of the Institute (reference 2948) and conducted in accordance with the Good Clinical Practice guidelines and the Declaration of Helsinki. All patients participated voluntarily and signed the informed consent document once the objectives and procedures of the study were explained.

\section{Subjects}

Patients who met the following inclusion criteria were included:

- Age between 18 and 65 years.

- IBD diagnosis corroborated by endoscopic, histopathological, radiological and biochemical study.

- Under treatment for at least 6 months at the clinic.

- Ability to read and write, in order to answer the evaluation instruments employed in the study.

Patients with any concomitant disease unrelated to IBD and that might contribute to the presence of fatigue (e.g., lung or heart disease, anemia, cancer, chronic kidney disease, etc.) were excluded.

\section{Evaluation procedure}

After informed consent was obtained, all patients were interviewed in order to record the main demographic and clinical variables, such as gender, age, level of education, marital status, occupation, age at diagnosis, time of evolution, extra-intestinal manifestations, and drug treatment. The disease activity index was assessed using Truelove and Witts criteria $^{17}$, as well as Harvey and Bradshow criteria ${ }^{18}$ for patients diagnosed with Crohn's disease. 
After demographic and clinical characteristics were obtained, each patient was handed the IBD-F and, to determine its discriminant validity given the association between sleep quality and fatigue in patients with $\mathrm{IBD}^{19,20}$, the Pittsburgh Sleep Quality Index (PSQI), for self-completion.

The IBD-F scale is designed to assess fatigue in patients with IBD based on patient experiences ${ }^{15}$ and includes three sections:

I. Fatigue severity and duration, made up of five items, with the first four being assessed on a five-point Likert severity scale (in which 0 indicates no fatigue, and 4 , extreme fatigue) and the fifth item, on a Likert scale with five frequency levels (from 0 [never] to 4 [always]).

II. Fatigue impact on daily activities, with 30 items rated on a five-point Likert frequency scale (from 0 [never] to 4 [always]).

III.Causes and other factors related to fatigue, consisting of five open-ended items.

We consider that patients with fatigue and with greater consequences related to it show higher sleep disturbances. The PSQI assesses the quality of sleep and its alterations in last month ${ }^{21,22}$, includes 18 items that evaluate seven areas related to sleep, all rated on a 0-to-3 Likert scale; total score is obtained with the sum of these areas (range, from 0 to 21 points) and a higher score is indicative of greater difficulties in falling asleep.

\section{Statistical analysis}

For the description of demographic and clinical characteristics, frequencies and percentages were used for categorical variables, and means, as well as standard deviations and ranges, for continuous variables. To determine the instrument construct validity, a factor analysis of each one of its sections was carried out, in accordance with the original proposal carried out by the creators of the instrument ${ }^{15}$. For its performance, it is indispensable for at least 200 subjects or five subjects for each item of the instrument to be included ${ }^{23}$

Once the IBD-F factors were identified, the reliability of its sections was evaluated using Cronbach's alpha, with values $>0.80$ being regarded as adequate to determine that the section is reliable. Finally, for discriminant validity to be determined, the sample was divided into patients with a score $\geq 1$ on IBD-F section I and without fatigue ( 0 points on IBD-F section I), as well as into those with a score $\geq 1$ on IBD-F
Table 1. Clinical characteristics of the sample $(\mathbf{n}=\mathbf{2 0 0})$

\begin{tabular}{|c|c|c|}
\hline & Median \pm SD & Range \\
\hline Age at IBD onset (years) & $33.8 \pm 11.9$ & $8-61$ \\
\hline Age at IBD diagnosis (years) & $34.2 \pm 11.9$ & 8.61 \\
\hline Evolution time (years) & $11.0 \pm 7.9$ & $1-43$ \\
\hline & $\mathrm{n}$ & $\%$ \\
\hline $\begin{array}{l}\text { Current clinical status of the condition } \\
\text { Active } \\
\text { Remission }\end{array}$ & $\begin{array}{c}71 \\
129\end{array}$ & $\begin{array}{l}35.5 \\
64.5\end{array}$ \\
\hline $\begin{array}{l}\text { Extra-intestinal manifestations ( } \mathrm{n}=39 \text {, } \\
19.5 \% \text { ) } \\
\text { Arthralgia } \\
\text { Uveitis } \\
\text { Spondylitis } \\
\text { Sclerosing cholangitis } \\
\text { Erythema nodosum } \\
\text { Sacroiliitis } \\
\text { Rheumatoid arthritis }\end{array}$ & $\begin{array}{c}28 \\
5 \\
4 \\
4 \\
3 \\
1 \\
1\end{array}$ & $\begin{array}{c}71.8 \\
12.8 \\
10.3 \\
10.3 \\
7.7 \\
2.6 \\
2.6\end{array}$ \\
\hline $\begin{array}{l}\text { Treatment at the time of the study } \\
\text { Aminosalicylates } \\
\text { Azathioprine } \\
\text { Steroids } \\
\text { Methotrexate } \\
\text { Adalimumab } \\
\text { Cyclosporine } \\
\text { Infliximab }\end{array}$ & $\begin{array}{c}172 \\
56 \\
55 \\
7 \\
7 \\
1 \\
1\end{array}$ & $\begin{array}{c}86 \\
28 \\
27.5 \\
3.5 \\
3.5 \\
0.5 \\
0.5\end{array}$ \\
\hline
\end{tabular}

IBD: inflammatory bowel disease; SD: standard deviation.

section II and without fatigue (0 points on IBD-F section II). Total score obtained on PSQI was compared by means of Student's t-test of independent samples. All analyses were carried out with the Statistical Package for the Social Sciences (SPSS), version 22, with alpha value being set at $p \leq 0.05$.

\section{Results}

\section{Demographic and clinical characteristics of the sample}

Two-hundred patients with IBD were included, out of whom $57.5 \%(n=115)$ were women and $42.5 \%$ $(n=85)$ were men, with a mean age of 45 years (SD $=12.1$, range: $19-67$ years), and 11.5 years of education ( $S D=3.5$, range: $0-18$ years). Most patients were married at the time of the study $(65 \%, n=130)$, $30 \%(n=60)$ were single and $5 \%(n=10)$ were widowed or divorced. Ninety six (48\%) had a paid job at the time of the study, followed by $22 \%(n=44)$ who were dedicated to household chores, $20 \%(n=40)$ were unemployed and $10 \%(n=20)$ were students. 
Table 2. Inflammatory Bowel Disease Fatigue Scale factor analysis results

1. ¿Cuál es su nivel de fatiga en este momento? (What is your fatigue level right now?)

0.855

2. ¿Cuál fue su nivel de fatiga más alto en las últimas dos semanas? (What was your highest fatigue level in the past 2 weeks?)

3. ¿Cuál fue su nivel de fatiga más bajo en las últimas dos semanas? (What was your lowest fatigue level in the past 2 weeks?)

4. ¿Cuál fue su nivel promedio de fatiga en las últimas dos semanas? (What was your average fatigue level in the past 2 weeks?)

5. ¿Cuánto tiempo al despertar se ha sentido fatigado en las últimas dos semanas? (How much of your waking time have you felt fatigued in the past 2 weeks?)

Eigen value

Variance (\%)

Cronbach's alpha

1. Tuve que dormir una siesta durante el día a causa de la fatiga ( / had to nap during the day because of fatigue)

2. La fatiga me impidió salir a eventos sociales (Fatigue stopped me from going out to social events)

0.694

3. No pude ir al trabajo ni a la escuela a causa de la fatiga (I was not able to go to work or college because of fatigue)

0.513

4. Mi desempeño en el trabajo o en la escuela fue afectado por la fatiga (My performance at work or education was 0.585 affected by fatigue)

5. Tuve problemas para concentrarme debido a la fatiga (I had problems concentrating because of fatigue)

0.534

6. Tuve dificultad para motivarme a causa de la fatiga (I had difficulty motivating myself because of fatigue)

0.550

7. No pude bañarme ni vestirme a causa de la fatiga (I could not wash and dress myself because of fatigue)

0.454

8. Tuve dificultad para caminar debido a la fatiga (I had difficulty with walking because of fatigue)

0.586

9. No pude conducir tanto como necesito debido a la fatiga (I was unable to drive as much as I need because of fatigue)

10. No pude hacer tanto ejercicio físico como quería por la fatiga (I was not able to do as much physical exercise as I wanted to because of fatigue)

11. Tuve dificultades para continuar con mis hobbies/intereses debido a la fatiga (I had difficulty continuing with my hobbies/interests because of fatigue)

12. Mi relación emocional con mi pareja fue afectada por la fatiga (My emotional relationship with my partner was affected by fatigue)

13. Mi relación sexual con mi pareja fue afectada por la fatiga (My sexual relationship with my partner was affected by fatigue)

14. Mi relación con mis hijos se vio afectada por la fatiga (My relationship with my children was affected by fatigue)

0.489

0.734

0.678

0.625

0.485

15. Me he encontrado mal humor debido a la fatiga (I was in low mood because of fatigue)

0.578

16. Me sentí aislado debido a la fatiga (I felt isolated because of fatigue)

0.658

17. Mi memoria se vio afectada por la fatiga (My memory was affected because of fatigue)

0.612

18. Cometí errores por la fatiga (I made mistakes because of fatigue)

0.638

19. La fatiga me irritó (Fatigue made me irritable)

0.618

20. La fatiga me hizo frustrarme (Fatigue made me frustrated)

0.660

21. Me siento confundido debido a la fatiga (I got words mixed up because of fatigue)

0.671

22. La fatiga me impidió disfrutar de la vida (Fatigue stopped me from enjoying life)

0.751

(Continued).. 
Table 2. (continued)

Section II. Fatigue impact

23. La fatiga me impidió tener una vida satisfactoria (Fatigue stopped me from having a fulfilling life)

24. Mi autoestima se vio afectada por la fatiga (My self-esteem was affected by fatigue)

0.650

25. La fatiga afectó mi confianza (Fatigue affected my confidence)

26. La fatiga me hizo sentir infeliz (Fatigue made me feel unhappy)

27. Tuve dificultades para dormir por la noche debido a la fatiga (I had difficulties sleeping at night because of fatigue)

28. La fatiga afectó mi capacidad para hacer mis actividades domésticas normales (Fatigue affected my ability to do all my normal household activities)

29. Tuve que pedir ayuda a otros por la fatiga (I had to ask others for help because of fatigue)

30. La calidad de mi vida se vio afectada por la fatiga (Quality of my life was affected by fatigue)

Eigen value

Variance (\%)

Main patient diagnosis was chronic idiopathic ulcerative colitis $(86 \%, n=172)$, followed by Crohn's disease $(13.5 \%, n=27)$, and one patient with indeterminate colitis $(0.5 \%)$. The remaining clinical characteristics are shown in table 1.

\section{IBD-F Scale validity and reliability}

Factor analyses of both IBD-F sections had appropriate adequacy values according to Kaiser-Meyer-Olkin value (section I, 0.84; section II, 0.89) and highly significant tests of sphericity $(p<0.001$ for both). The results of the matrix of the main components with IBD-F items factor loadings are shown in table 2. As it can be observed, items on sections I and II showed adequate factor loadings (higher than 0.40 ), which explained 68.3 and $38.4 \%$ of variance in sections I and II, respectively. Reliability of the instrument, evaluated by Cronbach's alpha, was higher than 0.80 in both sections.

Mean score for the total sample obtained on PSQI was $8.2 \pm 4.3$ standard deviation (SD), with a range of one to 19 points, which indicated moderate sleep disturbances. According to the presence or absence of fatigue, $87 \%(n=174)$ reported fatigue and $13 \%(n=26)$ did not. As for the impact of fatigue (section II), $17 \%(n=34)$ did not report repercussions and $83 \%(n=166)$ indicated secondary repercussions.

When PSQI total score was compared between these groups for discriminant validity to be obtained, patients without fatigue showed lower scores $(4.4 \pm 3.0 \mathrm{SD})$, in contrast with patients with fatigue $(8.8 \pm 4.1, t=-6.5$, $p<0.001)$. Similarly, patients without fatigue effects had lower PSQI scores, in contrast to those affected by fatigue $(4.8 \pm 2.9$ vs. $8.9 \pm 4.2, t=-6.3, p<0.001)$. The results of these comparisons show that IBD-F has an adequate discriminant validity.

\section{Discussion}

The purpose of the present study was to obtain the construct validity, discriminant validity, and reliability by evaluating IBD-F scale internal consistency in Mexican patients with IBD. This is the first IBD fatigue scale validated in Spanish for Mexican patients, and so far it is available in English for the population of the United Kingdom $^{15}$ and Denmark ${ }^{24}$, and in Portuguese for Brazil ${ }^{25}$.

Regarding the validation process in the Mexican population, we could observe that factor loadings were high in all items, which indicates conceptual adequacy in the measurement of fatigue (section I) and its consequences (section II), according to the original proposal of the scale. In addition, unlike the convergent validity obtained with other instruments such as the Multidimensional Fatigue Inventory (in the United Kingdom), the Fatigue Perception Scale (FACIT-F in Brazil) and the Hopital Anxiety and Depression Scale (HADS), our study sought to determine IBD-F discriminant validity with sleep disturbances evaluated using the PSQI. One of the main causes related to fatigue has been reported to be sleep disorders, which is why patients with symptoms of fatigue tend to experience sleep disturbances ${ }^{26}$. According to the results we obtained, IBD-F allows 
identifying patients who might have some sleep disturbance, thus conferring it an adequate discriminating capacity. Similarly, IBD-F showed high reliability values, similar to those obtained in other studies ${ }^{15,25}$, with values higher than 0.80 .

An important strength of the present research is the number of included patients, which was larger than that used in the validation of the instrument in other countries. Currently various pharmacological and non-pharmacological treatments are being evaluated for the management of fatigue in this type of patients ${ }^{27}$, who could directly benefit if this disorder is timely identified. Thus, having a scale for the evaluation of fatigue in patients with IBD validated in our population will allow gastroenterologists to reliably identify fatigue and its severity in patients with IBD, in order for available new techniques to be used for timely and comprehensive treatment.

\section{Conclusions}

The IBD-F scale has adequate validity and reliability for its use in Mexican patients with IBD and constitutes a tool that will help Spanish-speaking gastroenterologists to objectively identify symptoms of fatigue.

\section{Conflict of interests}

None.

\section{Funding}

No funding of any kind was received.

\section{Ethical disclosures}

Protection of human and animal subjects. The authors declare that no experiments were performed on humans or animals for this research.

Confidentiality of data. The authors declare that they followed the protocols of their work center on the publication of patient data.

Right to privacy and informed consent. The authors obtained informed consent from the patients or subjects referred to in the article. This document is in the possession of the corresponding author.

\section{References}

1. Patarca R. Cytokines and chronic fatigue syndrome. Ann N Y Acad Sci. 2006:933:185-200.

2. Barsevick AM, Cleeland CS, Manning DC, O'Mara AM, Reeve BB, Scott JA, et al. ASCPRO recommendations for the assessment of fatigue as an outcome in clinical trials. J Pain Symptom Manage. 2010;39:1086-99.
3. Ream E, Richardson A. Fatigue: a concept analysis. Int J Nurs Stud. 1996;33:519-29.

4. Romber-Camps MJ, Dagnelie PC, Hesselink-van de Krujis MA, Kester AD, Engels LG, van Deursen C, et al. Fatigue and health-related quality of life in inflammatory bowel disease: results from a population-based study in the Netherlands: the IBD-South Limburg cohort. Inflamm Bowel Dis. 2010;16:2137-47.

5. Jonefjäll B, Simrén M, Lasson A, Öhman L, Strid H. Psychological distress, iron deficiency, active disease and female gender are independent risk factors for fatigue in patients with ulcerative colitis. United Eur Gastroenterol J. 2017;6:148-58.

6. Chavarría C, Casanova MJ, Chaparro M, Barreiro-de Acosta M, Ezquiaga $E$, Bujanda $L$, et al. Prevalence and factors associated with fatigue in patients with inflammatory bowel disease: a multicenter study. J Crohns Colitis. 2019;13:996-1002.

7. Grimstad T, Norheim KB, Isaksen K, Leitao K, Hetta AK, Carlsen A, et al. Fatigue in newly diagnosed inflammatory bowel disease. J Crohns Colitis. $2015 ; 9: 725-30$.

8. Nocerino A, Nguyen A, Agrawal M, Mone A, Lakhani K, Swaminath A. Fatigue in inflammatory bowel diseases: etiologies and management. Adv Ther. 2010;37:97-112.

9. Fresán-Orellana A, Parra-Holguín, Yamamoto-Furusho JK. Mental health factor associated with fatigue in Mexican patients with inflammatory bowel disease. J Clin Gastroenterol. 2020;55:609-14.

10. Krupp LB, LaRocca NG, Muir-Nash J, Steinberg AD. The fatigue severity scale. Application to patients with multiple sclerosis and systemic lupus erythematosus. Arch Neurol. 1989;46:1121-3.

11. Kleinman L, Zodet MW, Hakim Z, Aledort J, Chan K, Krupp L, et al. Psychometric evaluation of the fatigue severity scale for use in chronic hepatitis C. Qual Life Res. 2000;9:499-508.

12. Chandran V, Bhella S, Schentag C, Gladman DD. Functional assessment of chronic illness therapy-fatigue scale is valid in patients with psoriatic arthritis. Ann Rheum Dis. 2007;66:936-9.

13. Yellen SB, Cella DF, Webster K, Blendowski C, Kaplan E. Measuring fatigue and other anemia-related symptoms with the functional assessment of cancer therapy (FACT) measurement system. J Pain Symptom Manag. 1997;13:63-74.

14. Dittner AJ, Wessely SC, Brown RG. The assessment of fatigue: a practical guide for clinicians and researchers. J Psychosom Res. 2004;56:157-70

15. Czuber-Dochan W, Norton C, Bassett P, Berliner S, Bredin F, Darvell M, et al. Development and psychometric testing of inflammatory bowel disease fatigue (IBD-F) patient self-assessment scale. J Crohns Colitis. 2014;8:1398-406.

16. Knowles SR, Graff LA, Wilding H, Hewitt C, Keefer L, Mikocka-Walus A. Quality of life in inflammatory bowel disease: a systematic review and meta-analyses-part I. Inflamm Bowel Dis. 2018;24:742-51.

17. Truelove SC, Witts LJ. Cortisone in ulcerative colitis; final report on a therapeutic trial. Br Med J. 1955;2:1041-8.

18. Harvey RF, Bradshaw JM. A simple index of Crohn's disease activity. Lancet. 1980;1:514.

19. Hashash JG, Ramos-Rivers C, Youk A, Chiu WK, Duff K, Regueiro M, et al. Quality of sleep and coexistent psychopathology have significant impact on fatigue burden in patients with inflammatory bowel disease. J Clin Gastroenterol. 2016;52:1-8.

20. Chrobak A, Nowakowski J, Zwolińska-Wcisło M, Cibor D, Prybylska-Feluś M, Ochyra K, et al. Associations between chronotype, sleep disturbances and seasonality with fatigue and inflammatory bowel disease symptoms. Cronobiol Int. 2018;35:1142-52.

21. Buysse DJ, Reynolds CF, Monk TH, Berman SR, Kupfer DJ. The Pittsburgh sleep quality index: a new instrument for psychiatric practice and research. Psychiatry Res. 1989;28:193-213.

22. Jiménez-Genchi A, Monteverde-Maldonado E, Nenclares-Portocarrero A, Esquivel-Adame G, Vega-Pachecho A. Confiabilidad y análisis factorial de la versión en español del índice de calidad de sueño de Pittsburgh en pacientes psiquiátricos. Gac Med Mex. 2008;144:491-6.

23. Tabachnick BF, Fidell LS. Using Multivariate Statistics. Boston: Allyn and Bacon; 2001.

24. Vestergaard C, Dahlerup JF, Bager P. Validation of the Danish version of inflammatory bowel disease self-assessment scale. Dan Med J. 2017;64:A5394

25. Lage AC, Carneiro-Olivera C, Delgado-Bomtempo-Batalha AP, Araújo AF, Czuber-Dochan W, Fonseca-Chebli JM, et al. The inflammatory bowel disease-fatigue patient self-assessment scale: translation, cross-cultural adaptaton and psychometric properties of the Brazilian version (IBD-F Brazil). Arq Gastroenterol. 2020;57:50-63.

26. Yamamoto-Furusho JK, Parra-Holguín NN, Fresán-Orellana A. P174 high frequency of fatigue and sleep alterations impact on the quality of life in Mexican patients with inflammatory bowel disease. J Crohns Colitis. 2020;14:S224-5.

27. Farrell D, Artom M, Czuber-Dochan W, Jelsness-Jørgensen LP, Nortn C, Svage E. Interventions for fatigue in inflammatory bowel disease. Cochrane Database Syst Rev. 2020;4:CD012005. 